\title{
TEOLOGICZNE KORZENIE WSPÓŁCZESNEGO KRYZYSU OJCOSTWA, PŁCI I RODZINY NA MARGINESIE PROMIENIOWANIA OJCOSTWA KAROLA WOJTYŁY
}

W 1995 roku w Stanach Zjednoczonych ukazała się głośna książka Ameryka bez ojców. Konfrontacja z naszym najważniejszym problemem spolecznym (Blankenhorn). Jej autor, David Blankenhorn, ukazywał nowy, zatrważający fenomen socjologiczny i kulturowy w społeczeństwie amerykańskim, jakim było pozbywanie się przez mężczyzn odpowiedzialności za swoje żony, dzieci i rodziny. Rok później znany socjolog David Popenoe publikuje książkę Życie bez ojca. Przekonujące dane, że ojcostwo i macierzyństwo sa niezbędne dla dobra dzieci i społeczeństwa (Popenoe).

Te dwie książki były początkiem prawdziwej lawiny publikacji dotyczących tematu społeczeństwa bez ojców i negatywnych konsekwencji tego smutnego zjawiska: Rodziny bez ojców. Ojcowie, malżeństwo i dzieci w amerykańskim społeczeństwie Davida Popenoe i Święty Józef. Ojciec Jezusa w spoleczeństwie bez ojców Leonardo Boffa w 2009 roku, Pokolenie bez ojców. Odkupienie biografii Johna Sowersa w 2010 roku, Fikcja ojca. Rozdziały dla pokolenia bez ojców Donalda Millera w 2011 roku, Kościót dla pozbawionych ojca: Model duszpasterstwa wobec najpilniejszego problemu społeczeństwa Marka Stronga w 2012 roku, Nowe zasady dla mężczyzn. Stawanie się mężczyzna w społeczeństwie bez ojców Tony Gaskinsa w 2013 roku, Ameryka bez ojców i Kościót Sama Mehaffie i Czy ojcowie maja jakieśs znaczenie? Co nauka mówi nam o rodzicach, czego dotąd nie zauważyliśmy Paula Raeburna

Prof. dr hab. JAROSŁAW KuPCZAK OP - kierownik Katedry Antropologii Teologicznej w Instytucie Teologii Dogmatycznej UPJP II i dyrektor Ośrodka Badań nad Myślą Jana Pawła II w Krakowie; adres do korespondencji: ul. Stolarska 12, 31-043 Kraków; e-mail: jaroslaw.kupczak@upjp2.edu.pl. ORCID: http://orcid.org/0000-0001-8609-296X. 
w 2014 roku, Bohater. Stawanie się mocnym ojcem, jakiego potrzebuja twoje dzieci Meg Meeker w 2017 roku'.

Prawie 30 lat przed początkiem tej książkowej fali rejestrującej konsekwencje amerykańskiej rewolucji seksualnej, niespełna 40-letni krakowski ksiądz opublikował książkę Miłość i odpowiedzialność, w której odpowiedzialność za drugą osobę uczynił centrum swojej filozoficznej analizy miłości między mężczyzną i kobietą. Wykład monograficzny „Miłość i odpowiedzialność”, na podstawie którego powstała ta najsłynniejsza chyba filozoficzna książka Wojtyły, był ostatnim z cyklu czterech wykładów, które w latach 1954-1958 zaprezentował na Wydziale Filozoficznym Katolickiego Uniwersytetu Lubelskiego (Kalendarium 130). W przypadku każdego z tych wykładów: „Akt i przeżycie etyczne”, „Dobro i wartość”, „Zagadnienie normy i szczęścia”, „Miłość i odpowiedzialność”, Wojtyła - zafascynowany dwoma sposobami myślenia: metafizycznym i fenomenologicznym - dokonuje równoległego rozważania na tych dwóch planach metodologicznych (Wojtyła, Wykłady lubelskie). Dlatego też jeden człon każdego z tych czterech tytułów wskazuje na analizę metafizyczną (akt, dobro, szczęście, miłość), drugi człon - na analizę fenomenologiczną (przeżycie etyczne, wartość, norma, odpowiedzialność).

Ten metodologiczny kontekst jest ważny dla zrozumienia treści każdego z czterech wykładów lubelskich, przede wszystkim „Miłości i odpowiedzialności”. Po wnikliwym przemyśleniu fenomenologicznych poglądów Maxa Schelera Wojtyła rozumie, że jednym z głównych problemów kultury XX wieku jest emotywizm, tzn. zatracenie obiektywnej perspektywy i osadzenie wartości jedynie w przeżyciach indywidualnego podmiotu (Wojtyła, Ocena możliwości zbudowania etyki chrześcijańskiej). Ten emotywistyczny błąd ma szczególnie fatalne konsekwencje dla właściwego rozumienia i praktykowania miłości, która z natury rzeczy dotyczy ludzkich uczuć i stąd tym bardziej potrzebuje obiektywnego ujęcia i osadzenia w obiektywnej prawdzie o tym, kim jest człowiek, co jest moralnie dobre i złe, czym jest ludzka wolność.

Całość filozoficznych analiz w książce Miłość i odpowiedzialność może być widziana jako próba fenomenologicznego, wiernego opisu subiektywnej i emocjonalnej strony ludzkiej miłości, oraz osadzenia tego bogactwa doświadczeń związanych z miłością i erotyką w obiektywnej, metafizycznej antropologii i etyce. W tej obiektywnej perspektywie miłość, która rozpoczyna się najczęściej od uczucia i przynosi ze sobą niezwykłe rozbudzenie i pogłębienie całej emocjonalnej sfery człowieka, ostatecznie musi być widziana jako dojrzały, czyli rozumny i wolny akt całej kochającej osoby (actus humanus), w którym bierze ona odpowiedzialność za całą drugą

\footnotetext{
${ }^{1}$ Por. Popenoe, Boff, Sowers, D. Miller, Strong, Gaskins, Mehaffie, Raeburn, Meeker.
} 
osobę, jej teraźniejszość i przyszłość, co oznacza także odpowiedzialność za zrodzone potomstwo. Tak rozumiana miłość stanowi akt całej osoby, a nie tylko wypadkową chwilowych emocji, które „dzieją się” na powierzchni, oraz jest skierowana ku całej drugiej osobie, a nie tylko ku niektórym jej cechom, jak na przykład uroda. Autor Miłości i odpowiedzialności nazywa taki akt ,afirmacją”; zakłada on dojrzałość i wzajemne poznanie się obu podmiotów (Wojtyła, Miłość i odpowiedzialność 115).

W spotkaniu mężczyzny i kobiety ważną rolę pełni ciało: męskie i żeńskie. W książce Miłość i odpowiedzialność, która stanowi pewne podsumowanie pierwszego okresu intelektualnego rozwoju Autora, znajdujemy pierwsze w jego myśli analizy różnicy seksualnej, która jest źródłem tego, co w swojej późniejszej twórczości nazwie „odwieczną fascynacją” między mężczyzną i kobietą (Jan Paweł II, Mężczyzną i niewiasta 172). Z wrażliwością i wnikliwością poety oraz fenomenologa Wojtyła śledzi podobieństwa i różnice we wzajemnym stosunku mężczyzny i kobiety; jego komentatorzy nazwą później ten fenomen „,asymetryczną wzajemnością” (Martin 231).

Mniej więcej z tego samego czasu, co filozoficzna książka Miłość $i$ odpowiedzialność, pochodzi niezwykły utwór poetycki Karola Wojtyły, Promieniowanie ojcostwa. W centrum dramatu znajduje się konflikt między dwoma humanizmami (antropologiami). Pierwszy z nich, za Charlesem Taylorem, nazwiemy „humanizmem wyłączającym" (exclusive humanism): aby zagwarantować człowiekowi właściwą godność, wielkość i rozwój, należy z jego życia wyłączyć wymiar transcendentny i religijny (por. Taylor 19). Religia, zależność od absolutnego Ty uwłacza bowiem człowiekowi i pomniejsza jego godność. Aby człowiek mógł dorosnąć i potwierdzić się w swojej autonomii, musi usunąć Boga Ojca ze swojej perspektywy.

Humanizm wyłączający opiera się na idei, która od czasu Oświecenia jest stałym elementem kultury Zachodu: to dzieci, które nie używają w pełni rozumu, potrzebują uproszczonego wyjaśniania świata dostarczonego przez religię. Podczas gdy dzieci potrzebują ojca i jego bajek, dorośli wyrastają z dzieciństwa i zależności od ojca, uniezależniają się, emancypują. Miarą dorosłości jest uniezależnienie od ojca, intelektualne i moralne stanięcie na własnych nogach. Od Immanuela Kanta poprzez Augusta Comte'a i Fryderyka Nietzschego słyszymy, że dorosły człowiek potrafi za pomocą własnego rozumu uzasadnić te prawdy, do których uzasadnienia wcześniej potrzebował religii.

Drugi rodzaj humanizmu obecny w dramacie Promieniowanie ojcostwa to humanizm integralny, otwarty: człowiek to homo religiosus - wymiar transcendentny i religijny należy do tych niezbywalnych elementów natury ludzkiej, które stanowią o jej wielkości, pięknie i godności, dopełniają ludzkie poszukiwanie prawdy. Te dwa, tak skontrastowane humanizmy zostają w dramacie Wojtyły przedstawione za pomocą przeciwstawienia: samotność - ojcostwo. 
Samotność jest fundamentalnym doświadczeniem każdego człowieka. W myśli Wojtyły znajdujemy dwa rozumienia samotności. Pierwsza, bardziej fundamentalna, jest doświadczana przez każdego mężczyznę i każdą kobietę, jest wyrazem osobowej godności człowieka i pewnej nieprzekazywalności, głębi osoby ludzkiej (incommunicabilitas) (Miłość i odpowiedzialność 26). Drugi rodzaj samotności jest skutkiem ludzkiego wyboru, grzechu, poprzez który człowiek zrywa więzi z innymi, ze wspólnotą. Dlatego też w dramacie Promieniowanie ojcostwa Wojtyła pisze, że samotność jest skutkiem jakiegoś upadku: „stanął on [człowiek - biblijny Adam] kiedyś na pograniczu ojcostwa i samotności" (449). Upadek polegał na tym, że Adam nie potrafił „udźwignąć ojcostwa, nie mógł mu sprostać” - zrzucił on „ojcostwo jak brzemię" (449).

W analizowanym dramacie Wojtyły „odrzucenie ojcostwa” możemy rozumieć dwojako. Po pierwsze, odrzucenie ojcostwa to opis sytuacji każdego człowieka po grzechu pierworodnym. Adam i Ewa odrzucili promieniowanie ojcostwa Ojca Niebieskiego, dlatego są wewnętrznie samotni. To kosmiczna, metafizyczna samotność każdego człowieka, której opisów pełna jest współczesna twórczość poetycka i literacka. Bohater sztuki Jean-Paul Sartre’a Diabet i Pan Bóg wyznaje: „Zabiłem Boga, ponieważ mnie oddalił od ludzi, a oto jego śmierć mnie jeszcze bardziej od nich oddala [...]. Jeżeli Boga nie ma, dlaczego dalej jestem sam, ja, który tak chciałem być razem ze wszystkimi” (Sartre 69)². Dramat Czekajac na Godota Samuela Becketta jest doskonałym obrazem tej metafizycznej samotności dzisiejszego człowieka, której towarzyszy brak nadziei (por. Beckett). Bohaterowie dramatu Becketta czekają, ale już nie wiedzą na co lub na kogo: na jakiegoś Godota. Przysłuchując się ich rozmowie, czytelnik odkrywa stopniowo, że bohaterowie dramatu ani nie wiedzą, kim jest tak naprawdę Godot, ani czy ktoś taki w ogóle istnieje, ani tym bardziej, czy przyjdzie. Ich oczekiwanie jest bez sensu, ale przecież człowiek musi na coś czekać.

W drugiej, doczesnej i horyzontalnej perspektywie odrzucenie ojcostwa to sytuacja każdego mężczyzny (i analogicznie - kobiety), który opiera się miłości i wybiera siebie, sprzeciwiając się w ten sposób podstawowemu prawu rozwojowemu swojej osoby. Takie odrzucenie ojcostwa i macierzyństwa, w odróżnieniu od jego wertykalnego znaczenia, to sprawa nie tyle grzesznego dziedzictwa, ile teraźniejszego wyboru każdego z nas. Takie odrzucenie ojcostwa (macierzyństwa) to egocentryczny wybór samego siebie.

Wojtyła sugeruje, że te dwa wymiary odrzucenia ojcostwa, wertykalny i horyzontalny, oraz dwa wymiary ludzkiej samotności są ze sobą związane. To właśnie

\footnotetext{
${ }^{2}$ Bohater dramatu Sartre'a Muchy skarży się zdziwiony: „Ach, jakże ja jestem wolny. I jaką doskonałą pustkę mam w duszy" (Sartre 20).
} 
ojcostwo w przypadku mężczyzn i macierzyństwo w przypadku kobiet są, zdaniem Wojtyły, najważniejszym sposobem wierności Ojcu Niebieskiemu i sposobem przyjęcia promieniowania Jego ojcostwa, a równocześnie prawdy swojej natury. Dojrzałość mężczyzny polega na ojcostwie (fizycznym bądź duchowym); podobnie, dojrzałość kobiety realizuje się w macierzyństwie (fizycznym bądź duchowym). Ojcostwo i macierzyństwo polega na trosce i wzięciu odpowiedzialności za drugą osobę. Miłość wymaga odpowiedzialności. W świetle tych poetyckich i teologicznych rozważań możemy popatrzeć raz jeszcze na filozoficzną antropologię zawartą w książce Miłość i odpowiedzialność, jako na polemikę z romantycznym, tylko emocjonalnym rozumieniem miłości.

Samotność Adama, o której mówi dramat Promieniowanie ojcostwa, jest próbą fenomenologicznego i równocześnie metafizycznego opisu sytuacji człowieka po grzechu pierworodnym, człowieka oddzielonego od Ojca Niebieskiego i równocześnie odwracającego się od własnego powołania i dojrzałości, ojcostwa i macierzyństwa, zaprzeczającego prawdzie o sobie. Ta samotność jest jednym ze sposobów opisania „społeczeństwa bez ojców”, społeczeństwa Piotrusiów Panów (Cataluccio). Możemy z uznaniem pomyśleć o tym niespełna 40-letnim księdzu, który w powojennym, zniszczonym i wygłodzonym Krakowie, na długo przed rewolucją kulturalną lat sześćdziesiątych, z proroczą precyzją szkicował zarys kulturowych problemów przeszłego postchrześcijańskiego Zachodu.

Na samotność człowieka można jeszcze spojrzeć z innej strony. W filozoficznej i teologicznej refleksji Wojtyły najbardziej fundamentalną prawdą o człowieku jest fakt jego stworzoności, z którego wyrasta prawda o fundującej naturę człowieka relacji z Bogiem. W tej wersji humanizmu otwartego na transcendencję, Bóg nie jest rywalem człowieka, a Boskie promieniowanie ojcostwa jest warunkiem integralnego rozwoju każdej osoby ludzkiej, mężczyzny i kobiety, czego pierwszym znakiem jest przyjęcie własnego ojcostwa/macierzyństwa, przekroczenie społeczeństwa bez ojców i matek.

Wbrew tezom humanizmu wyłączającego, to nie relacja z Bogiem alienuje człowieka, ale właśnie odcięcie od Boga i religijna samotność. Obecność Boga w człowieku nie ma charakteru obcego i heteronomicznego. W dramacie Wojtyły Adam w pewnym momencie mówi do Boga: „zawsze okazuje się w końcu, że nigdy nie jesteś przeciwko mnie. Wchodzisz w to, co ja nazywam samotnością, i rozbijasz opór, który ci stawiam. Czy można powiedzieć, że się wdzierasz? Czy tylko wchodzisz drzwiami, które i tak są otwarte? Nie uczyniłeś mnie zamkniętym, nie domknąłeś mnie” („Promieniowanie ojcostwa” 451).

W ujęciu Wojtyły samotność jest próbą opisu stanu człowieka oddzielonego od Boga. Określiliśmy to jako „humanizm wyłączający”; możemy mówić także o „humanizmie zamkniętym”. To drugie określenie tłumaczy się przez pierwsze: 
„wyłączający” w dramacie Promieniowanie ojcostwa znaczy „,zamknięty”. Adam w pewnym momencie mówi bowiem: „Przekonałem się, że nie jestem 'samotny'. Jestem daleko bardziej 'zamknięty'” (455).W innym miejscu Adam podejmuje refleksję na temat napięcia między humanizmem zamkniętym i otwartym: „Iluż ludzi zdobędzie się na przekonanie, że żaden z nas nie jest całością zamkniętą i ostateczną? Nosimy tylko w sobie treść, która w swej postaci absolutnej nas przerasta, a jesteśmy do niej przywiązani i od niej zależni” (455). To piękne określenie wskazuje na autotranscendencję człowieka - homo religious ${ }^{3}$. Człowiek w swoim właściwym znaczeniu jest przede wszystkim „odniesieniem do”. Coś przez niego przebłyska, promieniuje bądź nie. Tak jak w klasycznej metafizyce pojęcia transcendentalne: prawda, dobro i piękno ukazują odniesienie rzeczy pięknych, dobrych i prawdziwych do tego, czym jest prawda, dobro i piękno same w sobie.

Samotność jest opisem sytuacji, w której człowiek nie przyjmuje promieniowania ojcostwa Ojca Niebieskiego. Z tej grzesznej kondycji człowieka wybawia Chrystus, który wchodzi w samotność człowieka, aby na nowo uczynić nas dziećmi. Dopiero świadome stanie się Bożym dzieckiem umożliwia przezwyciężenie grzesznego dziedzictwa Adama w sobie i rozwój ludzkiej osobowości, którego pierwszym znakiem jest ojcostwo mężczyzn i macierzyństwo kobiet. W ten właśnie sposób dokonuje się „promieniowanie ojcostwa”.

Włoski personalista, komentator myśli Wojtyły, Massimo Serretti identyfikuje główny problem współczesności w dotknięciu naszych czasów pokusą prometeizmu i uczynienia człowieka absolutem, czy też - innymi słowami - ulegnięciu nietzscheańskiej idei woli mocy (por. Serretti 249, 255). Każdy konsekwentny prometeizm musi jednakże rozpocząć od takiej dekonstrukcji kultury i życia społecznego, aby zniknęły z tej przestrzeni te zjawiska, które sprawiają, że człowiek jest świadomy swojej ograniczoności i stworzoności, np. w sposób realistyczny stawiają człowiekowi pytanie o jego początek i kres. Początek i kres człowieka mają bowiem charakter z natury religijny; pokazują, że nie tworzymy siebie, ale zależymy od Innego. Serretti zwraca uwagę, że w tym świetle należy patrzyć na współczesny bunt przeciwko ojcostwu, a także na destrukcję tradycyjnego modelu rodziny i na próbę zniesienia różnicy płci. W prometejskiej kulturze tylko człowiek nadaje sens takim rzeczywistościom jak: ojcostwo i macierzyństwo, płeć, męskość, kobiecość, rodzina i małżeństwo. Natura okazuje się wyłącznie konstruktem kulturowym; mówi tylko o człowieku, nie odsyła do Boga. Zanim więc na naszych oczach rozpoczęła się w laboratoriach technologiczna abolicja ojcostwa poprzez procedurę in vitro,

\footnotetext{
${ }^{3} \mathrm{~W}$ swoim filozoficznym opus magnum Karol Wojtyła nazywa ten fenomen pionową, wertykalną transcendencją człowieka (por. „Osoba i czyn” 164).
} 
banki nasienia i praktykę anonimowych dawców, od dłuższego czasu dokonywała się już filozoficzna i teologiczna dekonstrukcja idei ojcostwa.

W pierwszej części tego tekstu była mowa o zniesieniu ,promieniowania ojcostwa" w zamkniętym, wyłączającym humanizmie postoświeceniowego Zachodu. To zniesienie „promieniowania ojcostwa” dokonuje się przez wyłączenie religii z kultury oraz - jako skutek - przez konsekwentny uwiąd nadziei, który odbiera mężczyznom i kobietom przekonanie i siłę do tego, by stać się matkami i ojcami. Teraz należałoby powiedzieć o drugim elemencie zniesienia „promieniowania ojcostwa", jakim jest zniesienie samego ojcostwa i macierzyństwa, co dokonuje się przez negację istnienia różnicy płciowej. W różnicy między mężczyzną i kobietą, a także w przekraczającym tę różnicę jednoczącym erosie każdy człowiek (ostatecznie rodzący się z tej zjednoczonej różnicy matki i ojca) spotyka kluczową zagadkę swojego życia. Oto mamy równość natury, a równocześnie nieprzekraczalną, choć trudno definiowalną różnicę.

W przypadku mężczyzny i kobiety mamy dwa pełne byty, które mogą żyć niezależnym, osobowym życiem. Równocześnie skonstruowane są one w taki sposób, że do pełni życia potrzebują siebie nawzajem. Nawet jeśli z różnych powodów nie zawrą nigdy małżeństwa, to przecież istnienie ojca i matki, mężczyzny i kobiety, którzy dali początek każdemu życiu, należy do duchowego DNA każdego człowieka. Nic dziwnego, że w pierwszym rozdziale biblijnej Księgi Rodzaju, mimo tego, że objawienie Boga jako Trójcy Osób (jedna natura - trzy osoby) pozostaje sprawą dalekiej przyszłości, obrazem Boga (imago Dei) zostaje nazwana wspólnota dwóch osób o jednej naturze: Adama i Ewy, z której rodzi się trzecia osoba o tej samej naturze, ich dziecko (por. Rdz 1,26-28).

Każdy myśliciel wrażliwy na tekst biblijny musi dostrzec teologiczne znaczenie płci. Dla Emmanuela Levinasa kluczowe dla bycia sobą, a także dla przekroczenia swojej samotności jest spotkanie z innym; szczególnie spotkanie mężczyzny i kobiety. Różnica płciowa jest podstawowym miejscem doświadczenia inności; w ten sposób staje się również fundamentem poznania wszelkiej innej różnicy między ludźmi. Czytamy w jednej z wczesnych książek Levinasa, która jest zapisem jego wykładów w Paryżu w latach tuż po zakończeniu II wojny światowej:

Trzeba uznać wyjątkowe miejsce tej relacji pośród innych relacji. Jest to relacja z innością, z tajemnicą, to znaczy z przyszłością, z tym, co w świecie, w którym wszystko jest tu-oto, nigdy nie jest tu, z tym, co może nie być tu, kiedy wszystko jest tu. Nie z jakimś bytem, którego nie ma, ale z samym wymiarem inności. Tu, gdzie wszystkie możliwości są już niemożliwe, tu, gdzie nie można już móc, podmiot ciągle jest jeszcze podmiotem dzięki erosowi. Miłość nie jest jedną z możliwości, nie powstaje dzięki naszej inicjatywie, jest bez racji, opanowuje nas i rani, a jednakże 'ja' (le je) się w niej ostaje. (Levinas 101) 
Zdaniem Levinasa, doświadczonego przez tragedię Holocaustu i szukającego nowej antropologii, która daje człowiekowi nadzieję, to właśnie relacja mężczyzny i kobiety jest relacją z przyszłością. Nie ma mężczyzny, nie ma kobiety - nie ma przyszłości. Stosunek pomiędzy różnicą płciową i przyszłością nie polega jedynie na rodzeniu dzieci, co oczywiście zapewnia przetrwanie ludzkiemu gatunkowi. Trzeba wszakże pamiętać, że w kulturze żydowskiej rodzenie dzieci jest niezwykle ważne dla przedłużenia etnicznego istnienia narodu wybranego, a w wypadku Levinasa bezpośrednim kontekstem przemyśleń filozoficznych jest właśnie kultura żydowska wraz z horrorem Holokaustu. Jednak różnica płci wskazuje na przyszłość także dlatego, że jest miejscem, gdzie każdy człowiek spotyka inność, której nie może objąć, może ją tylko zaakceptować i z nią żyć. Dlatego też właściwa relacja mężczyzny i kobiety nie jest posiadaniem drugiej osoby; nie jest walką, zjednoczeniem ani też poznawaniem. Nie jest posiadaniem, gdyż wolność drugiego wymyka się posiadaniu; nie jest walką, gdyż buduje jedność; nie jest wreszcie zjednoczeniem ani też poznaniem, gdyż w relacji z kochaną osobą pozostaje szacunek dla inności. Jest akceptacją i nadzieją.

W deterministycznym świecie, gdzie konieczność odebrała człowiekowi wolność i w związku z tym nadzieję, gdzie „wszystko jest tu oto”, to właśnie miłość mężczyzny i kobiety strzeże ludzkiej wolności: „Tu, gdzie wszystkie możliwości są już niemożliwe, tu, gdzie nie można już móc, podmiot ciągle jest jeszcze podmiotem dzięki erosowi”. Miłość, jak zawsze w historii, tak i teraz, porusza, wyzwala wolność i energię jednostek. Inność płci i związana z nią tajemnica płodności wyprowadza człowieka poza samego siebie, wzbogaca jego życie i je komplikuje, także - a może przede wszystkim - przez rodzenie dzieci, ale właśnie przez to czyni go człowiekiem. Dlatego też w świecie bez religii, bez tajemnicy i bez promieniowania ojcostwa różnica płci, różnica między ojcostwem i macierzyństwem musi zniknąć. Eros staje się przyjemnością instant, przyjemnością na zamówienie. Dochodzimy do „człowieka bez właściwości” Roberta Musila, ,człowieka jednowymiarowego” Herberta Marcuse, doskonałego konsumenta i klienta. Zastanawiamy się, czy naprawdę istnieje różnica między związkiem hetero- $\mathrm{i}$ homoseksualnym.

Szczególne znaczenie w relacjach znaczonych przez płeć Levinas przypisuje ojcostwu. Czytamy w jego paryskich wykładach:

Ojcostwo jest relacją z kimś obcym, kto będąc kimś innym, jest mną; jest to relacja Ja z samym sobą, które jednakże jest obce wobec Ja. Syn [córka - JK] w istocie nie jest po prostu moim dziełem, jak jakiś poemat czy wytworzony przedmiot; nie jest również moją własnością. Ani kategorie władzy, ani kategoria posiadania nie mogą naznaczać relacji z dzieckiem. Faktu płodzenia nie pozwalają uchwycić ani pojęcie przyczyny, ani pojęcie własności. Ja nie mam swojego dziecka; w pewien sposób jestem moim dzieckiem. Tyle tylko, że słowo 'jestem' ma tu znaczenie różne od znaczenia eleackiego, czy platońskiego. W czasowniku istnieć jest wielość i transcendencja, 
której właśnie brak w najbardziej odważnych analizach egzystencjalistycznych. Z drugiej strony, syn nie jest dowolnym wydarzeniem, które mi się przytrafia, jak na przykład smutek, różne doświadczenia losu lub cierpienie. Jest to Ja, osoba. (Levianas 105-106)

Trudno nie odnaleźć w tych refleksjach Levinasa bliskości do myśli Jana Pawła II, który powiedział: „w biologię rodzenia wpisana jest genealogia osoby” („List do Rodzin" nr 9).

Akt poczęcia nie jest aktem tworzenia, uczynienia człowieka. Mężczyzna i kobieta nie mają władzy nad procesem poczęcia, mogą starać się o dziecko, ale nigdy nie osiągną pewności, że w akcie seksualnym to poczęcie nastąpiło. Ten brak kontroli i władzy nad poczynającym się człowiekiem jest etycznym warunkiem i metafizycznym znakiem godności samego procesu poczęcia, jak również poczętej osoby, która jest obrazem i podobieństwem Boga (Rdz 1,26-27). Serretti zauważa, że w tym „braku kompetencji” i władzy nad nowym życiem małżonkowie okazują się być także dziećmi, to znaczy, także oni są „stworzeni i poczęci przez Innego" (Serretti 260). Poczynając są poczęci. Ojcostwo i macierzyństwo nie mają charakteru autoreferencyjnego; są przyjmowaniem i uczeniem się nowej dojrzałości, w czym ważna rola przypada także dziecku, które od początku przecież nie jest przedmiotem, ale podmiotem życia rodzinnego. To pochodzenie od Innego, które implikuje zależność i wdzięczność, sprawia, że człowiek nie może myśleć o sobie jako o absolucie. Sama struktura procesu poczęcia i wychowania przekreśla prometejski mit ${ }^{4}$. Istotą ludzkiego życia jest zależność, a znakiem ludzkiej mądrości jest wdzięczność (eucharistia) za to, co otrzymujemy od innych. „W biologię rodzenia wpisana jest genealogia osoby".

Kolejnym elementem ojcostwa, na który Levinas zwraca uwagę w cytowanym powyżej tekście, jest doświadczana przez rodziców wobec swoich dzieci wielość i transcendencja istnienia. Jeśli w jednoczącym akcie miłości mężczyzna i kobieta ekstatycznie wychodzą z siebie ku drugiemu i dokonują wzajemnej, budującej ich jedność autotranscendencji, to ta transcendencja aktu seksualnego ma również ważkie znaczenie etyczne i metafizyczne. Przypomina ona i oznacza, że w procesie poczęcia rodzice nie reprodukują siebie samych, mimo tego, że przekazują poczętemu dziecku cały materiał genetyczny. Poczęte dziecko transcenduje swoich rodziców, ponieważ jest nie tylko na obraz swoich rodziców, ale jest również na obraz i podobieństwo Boga (Rdz 1,26-27), który uczestniczy w każdym poczęciu dając dziecku nieśmiertelną duszę (Serretti 262). Dziecko to coś więcej niż rodzice, ktoś inny.

\footnotetext{
${ }^{4}$ Piękną, filozoficzną i teologiczną medytacją na ten temat jest książka Stephana Kampowskiego Contingenza creaturale e gratitudine, Cantagalli, 2012.
} 
W swojej fenomenologii inności Levinas jasno odróżnia ojcostwo od macierzyństwa; tutaj okazuje się tradycyjny w najlepszym tego słowa znaczeniu i radykalnie antykulturowy oraz bliski myśli Karola Wojtyły/Jana Pawła II. Dlaczego? W macierzyństwie matka ma zupełnie jedyną w swoim rodzaju relację z dzieckiem, które na początku, jako płód, jest jej częścią. Ojcostwo natomiast, jak zauważa francuski filozof, od początku jest „relacją z kimś obcym, kto będąc całkowicie kimś innym, jest mną; jest to relacja Ja z samym sobą, które jednakże jest obce wobec ja" (Levinas 105; por. Grabowski 51-58). Macierzyństwo i ojcostwo są dwoma komplementarnymi sposobami realizacji natury człowieka (natura humana); każdy domaga się odrębnej refleksji. Niemniej, jak śpiewa popularny zespół muzyczny, należy pamiętać, że „sanki są na zimę, rower jest na lato, mama to nie jest to samo, co tato".

Możemy więc zwrócić uwagę na trzy istotne elementy różnicy między ojcostwem i macierzyństwem. Po pierwsze, ojcostwo jest bardziej zewnętrzne wobec dziecka niż macierzyństwo. Dlatego też, po drugie, ojcostwo musi być zawsze przedmiotem świadomego wyboru i decyzji (Serretti 255-256) . Tej decyzji, w sposób oczywisty, wymaga także każde macierzyństwo, zwłaszcza we współczesnej epoce rozpowszechnienia się mentalności aborcyjnej; niemniej kobieta jest w pewien sposób lepiej przygotowana do podjęcia tej decyzji przez sam biologiczny rytm swego ciała. Trzecim elementem, na który chcemy zwrócić tutaj uwagę, jest fakt, że mężczyzna staje się ojcem przez kobietę - matkę, która pośredniczy między ojcem i dzieckiem.

Budujemy nasze rozważania wykorzystując analogię między Ojcem Niebieskim a ludzkim ojcostwem i macierzyństwem. Bóg zechciał zbawić ludzi przez Syna, który urodził się w ludzkiej rodzinie, różnica płci stała się zbawcza. Polski filozof, pracujący od wielu lat na Uniwersytecie Laterańskim w Rzymie, Stanisław Grygiel tak pisze o tym w swoim komentarzu do Promieniowania ojcostwa Karola Wojtyły: „Bóg wchodzi w samotność ludzi przez Syna. A więc, w samotność ludzi wchodzi On przez Kobietę [...] W Matce zaczyna się Nowe Życie. Każda matka jest miejscem spotkania ojca i syna. Ta jedyna Matka jest miejscem spotkania między Ojcem i synami [córkami - JK] w Synu" (Grygiel 167).

Grygiel wykorzystuje to wojtyłowe i levinasowskie spostrzeżenie, że mężczyzna staje się ojcem przez matkę, aby przenieść je - zgodnie z intencją Promieniowania ojcostwa - na plan nadprzyrodzony. W ekonomii zbawienia Boże dzieci: córki i synowie Ojca Niebieskiego, również spotykają się z Ojcem przez Matkę, a Ojciec niebieski „potrzebuje” Matki - Kościoła, aby móc spotkać się ze swoimi dziećmi, aby nawiązać z nimi swoją ojcowską więź. W tym znaczeniu sam fakt istnienia Kościoła broni różnicy płci.

${ }^{5} \mathrm{~W}$ tradycji żydowskiej religijna ceremonia ofiarowania dziecka w świątyni była właśnie momentem oficjalnego przyznania się ojca do własnego dziecka, por. J.W. Miller. 
Ludzki fenomen stawania się mężczyzny ojcem przez matkę Grygiel opisuje następująco: „ojciec poczynając syna w matce jest poczęty w synu. Na tym polega jego bycie oblubieńcem. Matka zaś, poczynając syna, wpisuje w niego ideę ojca [...] Przez matkę, tak jak przez witraż katedry, wchodzi na świat światło ojca, w które ona ubiera swoje dzieci" (Grygiel 169). Podążając za antropologicznymi i trynitarnymi refleksjami Wojtyły, Grygiel ukazuje, że w miłości ludzkiej rodziny, tak jak w miłości trynitarnej, równość i jedność idzie w parze z różnicą i hierarchią. Inna jest miłość matki, inna jest miłość ojca, inna jest miłość dziecka, córki i syna. Inna, a równocześnie ta sama, ponieważ pochodzi z jednego źródła. Tak jak jedno i to samo światło, przechodząc przez witrażowe szkiełka, mieni się bogactwem kolorów. Tej różnorodności nie powinniśmy zatracić w dzisiejszej, jednowymiarowej, spłaszczającej wszystko kulturze.

Dramat Promieniowanie ojcostwa dokonuje refleksji nad najbardziej podstawowymi rzeczywistościami w życiu każdego człowieka. Tematami podstawowymi są bowiem: ojciec, matka, dziecko, rodzenie, tożsamość osoby, miłość, samotność, więź. Jak mówi Adam w swojej ostatniej wypowiedzi, wskazując jakby na koniec czasu: „Wszystko inne okaże się wtedy nieważne i nieistotne, prócz tego jednego: prócz ojca, dziecka i miłości” (480).

\section{BIBLIOGRAFIA}

Beckett, Samuel. „Czekając na Godota”. Samuel Beckett. No właśnie co. Dramaty i proza. Przeł. Antoni Libera, PIW, 2010, ss. 9-91.

Blankenhorn, David. Fatherless America: Confronting Our Most Urgent Social Problem. Basic Books, 1995.

Boff, Leonardo. Saint Joseph: The Father of Jesus in a Fatherless Society. Cascade Books, 2009.

Cataluccio, Francesco. Niedojrzałość. Choroba naszych czasów. Przeł. Stanisław Kasprzysiak, Znak, 2006.

Gaskins,Tony A. The New Guy Code: Becoming A Man In A Fatherless Society. Soul Writers, 2013.

Grabowski, Marian. „Fenomenologia ojcostwa”. Marian Grabowski. Na ścieżkach współczesności, Homo Dei, 2003, ss. 51-58.

Grygiel, Stanisław. Dolce guida e cara. Cantagalli, 2008.

Jan Paweł II. „List do Rodzin z okazji Roku Rodziny 1994 Gratissimam sane”.

Jan Paweł II. Mężczyzna i niewiasta stworzyt ich. Odkupienie ciała a sakramentalność matżeństwa. red. Stanisław Dziwisz i in., Libreria Editrice Vaticana, 1986.

Kalendarium życia Karola Wojtyly, oprac. Adam Boniecki, Znak, 2000.

Levinas, Emmanuel. Czas i to, co inne. Przeł. Jacek Migasiński, Wydawnictwo KR, 1999.

MacIntyre, Alasdair. After Virtue: A Study in Moral Theory. University of Notre Dame Press, 1981.

Martin, Francis. „Nowy feminizm. Podstawy biblijne i niektóre kierunki rozwoju”. Kobiety w Chrystusie. W stronę nowego feminizmu. Tłum. Michał Romanek, red. Michele M. Schumacher, Centrum Myśli Jana Pawła II, 2008, ss. 203-238.

Meeker, Meg. Hero: Becoming the Strong Father Your Children Need. Regnery, 2017. 
Mehaffie, Sam. Fatherless America and the Church. CreateSpace Independent Publishing Platform, 2014.

Miller, Donald. Father Fiction: Chapters for a Fatherless Generation. Howard Books, 2011.

Miller, John W. Biblical Faith and Fathering: Why We Call God "Father". Paulist Press, 1990.

Popenoe, David. Families Without Fathers: Fathers, Marriage and Children in American Society. Routledge, 2009.

Popenoe, David. Life Without Father: Compelling New Evidence That Fatherhood and Marriage Are Indispensable for the Good of Children and Society. Free Press, 1996.

Raeburn, Paul. Do Fathers Matter? What Science Is Telling Us About the Parent We've Overlooked. Scientific American, 2014.

Sartre, Jean Paul. Dramaty. Tłum. Jerzy Lisowski, Jan Kott, PIW, 1956.

Serretti, Massimo. L'uomo è persona. Lateran University Press, 2008.

Sowers, John A. Fatherless Generation: Redeeming the Story. Zondervan, 2010.

Strong, Mark E. Church for the Fatherless: A Ministry Model for Society's Most Pressing Problem. InterVarsity Press, 2012.

Taylor, Charles. The Secular Age. Harvard University Press, 2007.

Wojtyła, Karol. Miłość i odpowiedzialność. Towarzystwo Naukowe Katolickiego Uniwersytetu Lubelskiego, 1986.

Wojtyła, Karol. Ocena możliwości zbudowania etyki chrześcijańskiej przy założeniach systemu Maksa Schelera. Towarzystwo Naukowe Katolickiego Uniwersytetu Lubelskiego, 1959.

Wojtyła, Karol. „Osoba i czyn”. Karol Wojtyła. Osoba i czyn oraz inne studia antropologiczne, red. Tadeusz Styczeń i in., Towarzystwo Naukowe Katolickiego Uniwersytetu Lubelskiego, 1994, ss. 43-344.

Wojtyła, Karol. „Promieniowanie ojcostwa”. Karol Wojtyła. Poezje, dramaty, szkice. Jan Paweł II. Tryptyk rzymski. Wstęp Marek Skwarnicki, Znak, 2007, ss. 447-480.

Wojtyła, Karol. Wyktady lubelskie, Towarzystwo Naukowe Katolickiego Uniwersytetu Lubelskiego, 1986.

\section{TEOLOGICZNE KORZENIE WSPÓŁCZESNEGO \\ KRYZYSU OJCOSTWA, PŁCI I RODZINY \\ NA MARGINESIE PROMIENIOWANIA OJCOSTWA \\ KAROLA WOJTYŁY}

Streszczenie

W żadnej epoce dotąd temat płci nie zajmował tak dużo miejsca w debacie akademickiej i publicznej. Zagadnieniom różnicy seksualnej, definicji męskości i kobiecości, oraz odpowiedzi na pytanie, w jakiej mierze płeć jest częścią natury, a w jakiej kultury, poświęcone są obecnie zawrotne ilości publikacji i sympozjów. Te kwestie, które dotąd zawsze były uważane za ważne tematy antropologiczne i etyczne, ale w debacie publicznej korzystały z pewnego konsensusu społecznego dotyczącego spraw oczywistych i niepodważalnych, oraz chroniły się w sferze tego, co prywatne i co dotyczy tajemnic życia domowego, dzisiaj straciły tę podwójną ochronę. Dramat Karola Wojtyły Promieniowanie ojcostwa, napisany w latach sześćdziesiątych ubiegłego wieku, w zaskakujący sposób antycypuje te współczesne dyskusje dotyczące płci oraz proponuje właściwą dla kultury Zachodu filozoficzną i teologiczną perspektywę, w której możliwe jest danie właściwych odpowiedzi na stawiane w tej dziedzinie pytania. W tej perspektywie te podstawowe dla każdego człowieka rzeczywistości egzystencjalne: bycie synem lub córką, matką lub ojcem, mężczyzną lub kobietą, mężem lub żoną, nie wskazują jedynie na sferę biologiczną człowieka, ani też nie mają charakteru umownego, który podlega dowolnym modyfikacjom. 
Raczej, we właściwym dla życia ludzkiego symboliczno-sakramentalnym ich odczytaniu, tworzą one duchowe DNA człowieka, z którego rozwija się to, co prawdziwie ludzkie.

Słowa kluczowe: Bóg Ojciec; rodzina; miłość; zróżnicowanie płciowe; Kościół, ateizm

\author{
THE THEOLOGICAL ROOTS OF THE MODERN \\ CRISIS OF FATHERHOOD, SEXUAL DIFFERENCES, AND THE FAMILY \\ ON THE MARGINS OF THE RADIANCE OF FATHERHOOD \\ BY KAROL WOJTYŁA
}

Sum mary

In no historical era have the topics of sex and gender occupied such space in academic and public debates. Today, an immense number of publications and conferences is devoted to subjects such as sexual differences, the definition of masculinity and femininity, the question whether and to what extent is sex part of nature, and to what extent of culture? These topics, always considered important in the anthropological and ethical fields, benefitted in the public debate from a certain social consensus on obvious and indisputable matters, as did those which were hidden from debate and concerned with that which is private and concerns the secrets of home life. Today, they have lost this double protection. Karol Wojtyła's drama The Radiance of Fatherhood, written in the 1960s, surprisingly anticipates these contemporary discussions and proposes a philosophical and theological perspective appropriate for Western culture in which it is possible to give the right answers to the questions posed. In this perspective, these basic existential realities for every human being - being a son or daughter, mother or father, man or woman, husband or wife - do not only point to the sphere of human biology, nor are they contractual and subject to modifications. Rather, in the symbolic and sacramental interpretation which is proper to human life, they form the spiritual DNA of any human being from which that which is truly human can develop.

Keywords: God the Father; family; love; sexual difference; Church; atheism 